M. A. Katritzky

\title{
Stefanelo Botarga and Pickelhering: Fishy Italian and English Stage Clowns in Spain and Germany
}

Juliet's wishful pronouncement on the name of the rose applies even less to comic stage names than to flowers. ${ }^{1}$ Cultural expectations shape every aspect of our perceptions, and the funny business of early modern travelling actors is enhanced by well-chosen stage names; even more so if they have strong regional associations. With reference to new textual and iconographic evidence, this article focuses on the origins, transnational diffusion and significance of two stage names based on fish specialities with specific regional associations: as names, as Italian and English stage roles and as popular stock festival costumes, both within their Spanish- and German-speaking host regions, and beyond.

1 William Shakespeare, Mr William Shakespeares comedies, histories, \& tragedies: Published according to the True Originall Copies (London: Iaggard \& Blount, 1623), p. 59 (Romeo and Juliet[, 2.2.43 f.]: “[T]hat which we call a Rose, / By any other word would smell as sweete").

Note: My thanks to the organisers and participants of events at which earlier versions of this work were presented and discussed: Martin Procházka: Renaissance Shakespeare/Shakespeare Renaissances, International Shakespeare Association 9th World Congress, Prague, July 2011 (ISA Seminar 17: Shakespearean Players in Early Modern Europe, co-chaired with Pavel Drábek); Volker Bauer and my Herzog August Bibliothek and Theater Without Borders friends and colleagues: Borders and Centres: Transnational Encounters in Early Modern Theatre, Performance and Spectacle, Theater Without Borders Annual Workshop 2012 at the Herzog August Bibliothek, Wolfenbüttel, May 2012; Friedemann Kreuder: Cartographies of the European Past: Nation, Region, Trans-Nation (The Presence of the Past: European Cultures of Memory, International Summer Schools 2010-2012, IPP Performance and Media Studies, keynote: “Transnational Discourses on Travelling Stages: Fishy Funny Business with Mediterranean Botarga and North Sea Pickle Herring"), Johannes Gutenberg Universität Mainz, July 2012; Hiram Kümper and Vito Gironda: Gleichheit/ Ungleichheit (220023-2. Teil-GK-SoSe 2012: “Equality/ Inequality: On and Around Early Modern European Travelling Stages”), Universität Bielefeld, July 2012; Joachim Küpper, Gautam Chakrabarti, Leonie Pawlita and Madeline Rüegg: Theatre Cultures within Globalising Empires: Looking at Early Modern England and Spain, DramaNet, Freie Universität Berlin, November 2012: this text version submitted 25 March 2013). For supporting this research, my thanks also to The Open University Arts Faculty Research Committee and the Herzog August Bibliothek and its staff and Fellows, most especially Ulrike Gleixner, Jill Bepler, Volker Bauer, UIrich and Birgit Kopp, Asaph Ben-Tov, Bob and Pauline Kolb, Cornelia Niekus Moore and Charlotte Colding Smith (Herzog August Bibliothek Visiting Fellowship, Summers 2011, 2012). 
Widespread opportunities for long-term co-ordinated professional acting were developed only during the sixteenth century, by actors who introduced many of the significant features of organised professional drama as we know it today, including year-round availability of performances, the participation of female as well as male actors, and above all the trans-regional mobility of performing groups. Theatre was an important part of medieval life in every European region. But the profession of wandering minstrel was economically challenging. Such entertainers faced widespread civic and church disapproval, expressed in harsh, unpredictable legal restrictions. Not least, these restrictions reflected strict calendar regulations prohibiting the year-round performance required by professionals wishing to earn their living on the stage. Court-, community- and above all Church-controlled feasts and fasts, of diverse length and type, punctuated and defined the early modern festive year. They restricted the activities of performers to specific dates and seasons, centred around the major Church feasts. Although the exact dates and regulations varied from one region to another, these excluded Lent and the other fasting days on which it was compulsory to eat fish rather than meat. During the medieval period, organised theatre largely consisted of amateur performances. Their actors were men and boys who belonged to schools and universities, city guilds, church congregations or courts. They returned to their studies or occupations when the performance was over. Increasingly, some of these amateur actors thought about ways of making performing a more economically secure long-term career prospect. By the mid-sixteenth century, musicians and entertainers were signing contracts to band together in formal groups with ambitious cultural and economic aims.

Although no European region was without its own characteristic amateur performance culture, not every region was equally successful in exporting professional players. By the late seventeenth century, actors of many nations routinely toured Europe. During the late sixteenth century and early seventeenth century, the situation was very different. Viable transnational brands of professional theatre were then mainly exported from two European language areas, to audiences in two broadly overlapping geographic host regions. Firstly, from the mid-sixteenth century onwards, the commedia dell'arte developed by male and female actors speaking the conglomerate of regional dialects that form the basis for the modern Italian language was performed in the Mediterranean regions. Secondly, from the 1580s onwards, itinerant professional all-male acting troupes from the English-speaking islands started touring European countries in the North Sea regions. Despite the disruptions of the Thirty Years' War, they exported their "English comedy" to mainland Europe for over a century.

Long expensive journeys required considerable financial incentives, and players who travelled had to be flexible enough to accommodate local regulations, 
confessional practice and linguistic barriers. For all these reasons, the Italian actors generally travelled to France and Spain, performing a repertoire addressing Catholic audiences, while the English actors favoured the German-speaking regions, mostly offering Protestant repertoires. Both Italian and English troupes developed innovative promotional strategies for challenging the traditional restrictions of the Christian festive year, and for encouraging prominent court and civic patrons to finance their travel expenses. Patronage was key. Wealthy French, Italian and Habsburg rulers recommended Italian players from one court to another with Habsburg family connections. Close relations between Queen Anne (wife of King James of England and sister of King Christian of Denmark) and the rulers of many northern European courts provided a ready-made patronage network for travelling English players. Troupes also modified their travel plans to accommodate lucrative non-performing economic activity. Many smaller commedia dell'arte troupes used free outdoor performances of the type that flourished in warm, dry southern climates to promote medical goods and services. English actors, especially those enjoying court patronage, often had diplomatic duties, or dealt in arms, musical instruments, luxury goods or cloth, either between courts or at the large trade fairs.

Germany's reputation as an attractive, lucrative hub for international itinerant performers, established in the late sixteenth century, was increasingly damaged by the Thirty Years' War, which devastated central Europe from 1618 to $1648 .^{2}$ The Mediterranean and North Sea regions were linked by the Habsburg lands. Strenuous political attempts to bring England into the Habsburg fold repeatedly foundered. In 1558 following the childless death, after four years of marriage, of King Philip II of Spain's Catholic second wife, Queen Mary I of England (daughter of Henry VIII and Philip's great-aunt Catherine of Aragon), his suit was rejected by Elizabeth I, Mary's half-sister and Protestant successor. In 1623, continued Spanish insistence on Prince Charles' conversion to Catholicism finally led King James I to abandon his decade-long negotiations to marry his heir to Philip II's granddaughter, the infanta María Ana. During the early modern period, Spain and Germany imported rather than exported professional drama. Through its wealthy courts, Europe-wide cultural contacts and international business centres, the Habsburg Empire established itself as the great early modern contact zone for professional Italian and English travelling troupes. The Inquisition's persecution of actresses made Spain an increasingly unattractive destination for

2 Pavel Drábek and M. A. Katritzky, “Shakespearean Players in Early Modern Europe,” in: Bruce R. Smith, ed., The Cambridge Guide to the Worlds of Shakespeare, 2 vols. (Cambridge/New York: Cambridge University Press, 2016), vol. 2 (The World's Shakespeare, 1660-present), pp. 1527-1533. 
mixed gender Italian troupes after 1586, and women were definitively banned from Spanish stages in $1596 .^{3}$

Stefanelo Botarga and Pickelhering, the two fish-inspired comic stage names of early modern itinerant actors under consideration here, both have very specific regional associations. One derives from the Mediterranean delicacy botargo, the other from the North Sea speciality Bückelhering or pickle herring. Stefanelo Botarga is a stock role created around 1570 by an Italian actor in Spain. Pickelhering, the most popular stage clown of the early seventeenth-century English actors in the German-speaking regions, was created somewhat later. ${ }^{4}$ The Oxford English Dictionary documents two definitions of the term "pickle herring." 5 Since the fifteenth century, it has denoted a specific type of preserved herring, a popular fish speciality in North Sea regions of The Netherlands, England, Germany and Scandinavia. A second meaning, of "a clown, a buffoon," recorded in Germany from c. 1610, officially entered common English usage only in the eighteenth century. Rare but notable much earlier occurrences linked to this second usage occur in the works of several prominent English dramatists and writers, such as Gabriel Harvey (1593), ${ }^{6}$ Thomas Dekker $(1607)^{7}$ or William Shakespeare, whose eponymously windy and flatulent old drunkard Sir Toby Belch in Twelfth Night, written around 1601, robustly curses "these pickle herring."8

As well as the meanings of "fish" and "clown," a third definition was explored by John Alexander, in an article of 2003 linking the expression to a particular

3 Teresa Ferrer Valls, "La representación y la interpretación en el siglo XVI,” in: Javier Huerta Calvo, ed., Historia del teatro español, 2 vols. (Madrid: Gredos, 2003), vol. 1, pp. 239-267, pp. 260-263.

4 On Pickelhering (and on a fish-based comic stage name not here considered, Stockfisch), see Katritzky, "Pickelhering and Hamlet in Dutch Art: The English Comedians of Robert Browne, John Greene, and Robert Reynolds," Shakespeare Yearbook 15 (2005), pp. 113-140, p. 120; Katritzky, “'A Plague o' These Pickle Herring': From London Drinkers to European Stage Clowns,” in: Martin Procházka, Michael Dobson, Andreas Höfele, and Hanna Scolnicov, eds., Renaissance Shakespeare, Shakespeare Renaissances: Proceedings of the Ninth World Shakespeare Congress (Newark: University of Delaware Press, 2014), pp. 159-170.

5 “pickle-herring, $n$.," in: John A. Simpson, ed., Oxford English Dictionary, $3^{\text {rd }}$ ed. (Oxford: Oxford University Press, 2000-in progress), Oxford English Dictionary Online, http://www.oed.com/ view/Entry/143422 (retrieved: 19 April 2012).

6 Gabriel Harvey, Pierces Supererogation or A new prayse of the Old Asse: A Preparatiue to certaine larger Discourses, intituled Nashes S. Fame (London: Iohn VVolfe, 1593), sig. Ff4v (quoted below).

7 Thomas Dekker, A knights Coniuring. Done in earnest: Discouered in Iest (London: William Barley, 1607), sig. Lr (quoted below).

8 Shakespeare, Comedies, histories, \& tragedies, p. 258 (Twelfe Night, Or what you will, 1.5). 
type of heavy social drinking in early modern Holland. ${ }^{9}$ My researches interrogate ways in which disputed pre-eighteenth-century English usages of the expression "pickle herring" relate to its adoption as a stage name. Using this third definition as a key to their interpretation, I draw on previously unconsidered archival documents to support "pickle herring” as a term associated with heavy drinkers. But I identify this usage's origins not in seventeenth-century Holland but in a quite specific sixteenth-century English location, Southwark in the 1580s.

The earliest undisputed English use of Pickelhering as a generic comic stage name is in 1656, by Richard Flecknoe, who may have seen professional English actors during his 1650 visit to the Brussels court of Beatrix of Lorraine. ${ }^{10}$ In the German-speaking regions it occurs already in two instrumental medleys transcribed in a Linz organ manuscript of c. 1611. The initial bars of one, "Tantz Pückelhäring," are based on music for "Nobodyes Gigge” composed by Richard Farnaby, an English lutenist employed at the North German court of Wolgast in the 1620s. ${ }^{11}$ The Wolfenbüttel court's close family connections with English royalty made it a favoured destination for English players, who were based there for many years from the 1590s. Wolfenbüttel archival court records of around 20 May 1615 confirm Pickelhering as the stage name of the English actor George Vincent. ${ }^{12}$ Pickelhering is named and depicted as a clown role in a collection of play-texts based on performances by the English players in Germany, published in Germany in $1620,{ }^{13}$ and in two German broadsheets of $1621,{ }^{14}$ and Netherlandish Pekelharing performers are also recorded from $1621 .^{15}$

9 [Robert] John Alexander, “The Dutch Connection: On the Social Origins of the Pickelhering," Neophilologus 87 (2003), pp. 597-604.

10 Richard Flecknoe, The Diarium, or Journall: Divided into 12 Jornadas in Burlesque Rhime or Drolling Verse (London: Henry Herringman, 1656), sig. A3v; Katritzky, Women, Medicine and Theatre, 1500-1750: Literary Mountebanks and Performing Quacks (Aldershot/Burlington, VT: Ashgate, 2007), p. 153.

11 John M. Ward, “The Morris Tune,” Journal of the American Musicological Society 39.2 (1986), pp. 294-331, pp. 306 f.; Alexander, "Will Kemp, Thomas Sacheville and Pickelhering: A Consanguinity and Confluence of Three Early Modern Clown Personas,” Daphnis 36 (2007), pp. 463486, pp. $467 \mathrm{f}$.

12 Niedersächsisches Hauptstaatsarchiv, Hannover, Kammerrechnungen Cal. Br. 21, Nr. 1756, fol. 49r; see Willem Schrickx, "'Pickleherring' and English Actors in Germany,” Shakespeare Survey 36 (1983), pp. 135-147, p. 139; Schrickx, Foreign Envoys and Travelling Players in the Age of Shakespeare and Jonson (Wetteren: Universa, 1986), pp. 235-238.

13 [Fridericus Menius, ed.,] Engelische Comedien vnd Tragedien Das ist: sehr schöne / herrliche vnd außerlesene / geist- vnd weltliche Comedi vnd Tragedi Spiel / Sampt dem Bickelhering (s.l., 1620).

14 Katritzky, "Pickelhering and Hamlet," pp. 129 f., figs. 4 and 5.

15 Gregor J. M. Weber, "'t Lof van den Pekelharingh: Von alltäglichen und absonderlichen Heringsstilleben,” Oud Holland 101.2 (1987), pp. 126-140, p. 139, n. 28. 
Updated renaming perhaps accounts for the Pickle Herring role of the Revesby sword play, cited by some scholars as evidence for this stage name's pre-Shakespearean English provenance. Regardless of the date of the performance practice it actually reflects, the Revesby sword play's earliest known manuscript (dated 1779 and first published only in 1889) is plausibly identified as "an eighteenth-century composite." ${ }^{16}$ Possibly, the popularity of visiting English actors inspired Andreas Gryphius to give the name Pickelhäring to the equivalent character to Shakespeare's Bottom in Absurda comica oder Herr Peter Squentz, his 1658 version of the Pyramus and Thisbe episode familiar from Midsummer Night's Dream. Other specialists have suggested that the Pickelhering name was popularised by Faustus, which Baron Waldstein saw performed by English comedians in Strasbourg as early as $1592 .{ }^{17}$ By 1604 , when the first edition of Marlowe's Faustus features "Pickle-herring" as a proper name, the term clearly evoked much more than simply fish for English theatre audiences. According to traditional scholarship, when the sin Gluttony introduces himself to Dr Faustus as the Godson of "Peter Pickle-herring,"18 this name refers to a "carnivalesque social type" with "a craving for [...] herring," ${ }^{19}$ and to the use of Lenten fish symbolism, of the type reflected in Pieter Bruegel's Battle of Carnival and Lent of 1569 and early modern derivations by lesser artists. ${ }^{20}$

In addition to carnival associations, the complex London social connotations of Christopher Marlowe's use of the name "Peter Pickle-herring" suggest the negative usage of the word "pickle," in the sense of a regrettable chaos or mess, as

16 Thomas Fairman Ordish, “Morris Dance at Revesby,” The Folk-Lore Journal 7.5 (1889), pp. 331356; Michael J. Preston, “The Revesby Sword Play,” The Journal of American Folklore 85.335 (1972), pp. 51-57, p. 57.

17 Julian Hilton, “Pickelhering, Pickleherring and What You Will," in: Jean Pierre Vander Motten, ed., Elizabethan and Modern Studies: Presented to Professor Willem Schrickx on the Occasion of His Retirement (Gent: Seminarie voor Engelse en Amerikaanse Literatuur, R.U.G., 1985), pp. 131-142, p. 134.

18 Christopher Marlowe, The Tragicall History of D. Faustus (London: Thomas Bushell, 1604), sig. C4v.

19 Alexander, "Will Kemp,” p. 466; see also Alexander, “Ridentum dicere verum (Using Laughter to Speak the Truth): Laughter and the Language of the Early Modern Clown 'Pickelhering' in Geman Literature of the Late Seventeenth Century (1675-1700),” in: Albrecht Classen, ed., Laughter in the Middle Ages and Early Modern Times: Epistemology of a Fundamental Human Behavior, its Meaning, and Consequences (Berlin/New York: De Gruyter, 2010), pp. 735-766, p. 766; Frederick B. Jonassen, "The Meaning of Falstaff's Allusion to the Jack-a-Lent in The Merry Wives of Windsor,” Studies in Philology 88.1 (1991), pp. 46-68, p. 55, pp. 59 f.

20 For Carnival and Lent depictions, see Katritzky, The Art of Commedia: A Study in the Commedia dell'Arte 1560-1620 with Special Reference to the Visual Records (Amsterdam/New York: Rodopi, 2006), pp. 422-424, plates 86-88. 
in 1565, when Hozjusz notes that a group of disputing theologians "[...] left the matter in as euell a pyckell as they founde it." ${ }^{21}$ Previously unrecognised is their direct reference to an actual historical figure, whose nickname came to the attention of the community of actors, dramatists and writers working and socialising in late sixteenth-century Southwark. This is the Flemish beer brewer Peter Van Durant, resident in the Southwark parish of St Olave's, whose will of 25 September 1584, identifies him as "Peter van Durant alias Picklehearinge" (confirmed in the marginalia as "Petri van Durant alias Picklehering"). ${ }^{22}$ Decades before its theatrical adoption is recorded in Europe, "Pickelhering" is thus documented as the nickname of a Flemish resident of Southwark. A short walk downstream the River Thames from London's Southbank theatre district, St Olave's Parish was commonly known as "Pickle Herring" until its wholesale destruction in 1999 to make way for City Hall, the present headquarters of the Greater London Authority. Several of its streets, buildings and landmarks had evidently acquired the Pickleherring name by 1596, by when "John Welshaw, a brewer, had taken a house and yard 'on backside at Pikell Herringe'."23 By 1612, documents are referring to the local quay as "Pekelharing Kay."24

Tavern owners have always known that cheap salty snacks promote the sale of alcohol. In early modern London, social drinking required salted meats and fish, especially herrings, then classified by three colours: green, white and above all red. Green, or fresh herrings were not economically viable, as they spoiled faster than they could be distributed. Traditionally, Londoners consumed cheap preserved herrings as the red-or smoked-herrings now known as kippers and bloaters, and the white herrings preserved with salt but without smoke. A third method of preserving herrings, the Flemish "pickled herring," was introduced to London only in the late sixteenth century. Alexander Addlehead, a fictional Scot featured by the pseudonymous Philip Foulface, offers the God Bacchus "[...] a dozen of red herrings to season his mouth before he sat downe to taste his

21 Stanisław Hozjusz, A most excellent treatise of the begynnyng of heresyes in oure tyme [De origine haeresium nostri temporis], trans. Richard Shacklock (Antwerp: Æg. Diest, 1565), fol. 23r. 22 National Archives, Kew, London (Records of the Prerogative Court of Canterbury: Will Registers, Ref. PROB 11/67/312). See also William Rendle, “Pickell Heringe," Notes and Queries 7 (1886), p. 209; Rendle and Philip Norman, The Inns of Old Southwark and Their Associations (London/ New York: Longmans, Green, 1888), p. 36.

23 P. 32.

24 Isobel Davies, "Seventeenth-Century Delftware Potters in St Olave's Parish, Southwark," Surrey Archaeological Collections Relating to the History and Antiquities of the County 66 (1969), pp. 11-31, p. 12, p. 15. 
liquor," 25 and Thomas Nashe writes of “[...] some shooing horne to pul on your wine, as a rasher of the coles, or a redde herring [...],"26 and elsewhere notes, "Heere I bring you a redde herring, if you will finde drinke to it, there an ende [...]"; ${ }^{27}$ in 1600, Cornwallis refers to "a pickled Herring to bring on drinke."28 Possibly, the Southwark brewer Peter Van Durant earned his nickname "Pickelhering" by promoting in his Southwark beer taverns this common staple food of Flanders, still viewed as an exotic promoter of alcoholic consumption as late as the 1580 s by Londoners.

Many impoverished, hungry drinkers damaged their health by overindulging in cheap beer tavern herrings. Most notoriously, the English writer Robert Greene's death on 3 September 1592 was attributed to a surfeit of Flemish pickled herrings and German white wine. The sorry circumstances of his death made a deep impression far beyond his immediate circle, and were gloatingly mocked by his literary arch-enemy Gabriel Harvey. Harvey deplored Greene's gluttonous and sinful lifestyle, his illegitimate son Fortunatus (mockingly dubbed Infortunatus by Harvey), who died in $1593,{ }^{29}$ and his "[...] infamous resorting to the Banckeside, Shorditch, Southwarke, and other filthy hauntes [...]." ${ }^{30}$ Deriding the habitual heavy drinking of Greene's immediate circle, Harvey mocks Thomas Nashe's fondness for "a goblet of rennish wine [...] a pickle-herring” and his "notorious surfett of pikle herring," and dismisses the man himself as a "Pickle-herring clarke" whose publications are "[...] but lenten stuff, like the old pickle herring[.]"31 Robert Greene's death informs many publications of the 1590s. Particularly striking are the conversations in Hell between deceased writers and actors in which Thomas Dekker has the recently deceased Thomas Nashe identify

25 Philip Foulface, Bacchvs Bovntie, Describing the debonaire dietie of his bountifull godhead, in the royall obseruance of his great feast of Pentecost (London: Henry Kyrkham, 1593), sig. Cv.

26 Thomas Nashe, Pierce Penilesse, his svpplication to the Diuell (London: I[ohn] B[usbie], 1592), sig. Fr.

27 Nashe, Nashes Lenten Stuffe, Containing, the Description and first Procreation and Increase of the towne of Great Yarmouth in Norffolke: With a new Play neuer played before, of the praise of the Red Herring (London: N[icholas] L[ing] and C[uthbert] B[urby], 1599), sig. A3r.

28 William Cornwallis, Essayes (London: Edmund Mattes, 1600), essay 43, sigs. Ee4r-Gg2v, sig. Ee5v.

29 Lori Humphrey Newcomb, “Greene, Robert (bap. 1558, d. 1592),” in: Henry Colin Grey Matthew and Brian Harrison, eds., Oxford Dictionary of National Biography (Oxford: Oxford University Press, 2004), online ed., ed. Lawrence Goldman, 2008, http://www.oxforddnb.com/view/ article/11418 (retrieved: 11 September 2011).

30 Harvey, Fovre Letters, and certaine Sonnets: Especially touching Robert Greene, and other parties, by him abused: But incidently of diuers excellent persons, and some matters of note (London: John Wolfe, 1592), pp. 9 f., quote on p. 10.

31 Harvey, Pierces Supererogation, sig. Ff4v and pp. 61-63; italics in the original. 
his own cause of death with that of his friend Greene, by "[...] invey[ing] bitterly (as he had wont to do) against dry-fisted Patrons, accusing them of his vntimely death [...]" because if they had not short-changed him he would "[...] not so desperately haue ventur'de his life, and shortend his dayes by keeping company with pickleherrings [...]."32 An oblique reference of 1600 to Robert Greene as a "worthy" drunkard "[...] whom diuers Dutchmen held full deare, / Was stabb'd by pickeld Hearings \& strong Beere[.]"33 suggests that the circle of writers and actors around Robert Greene and Thomas Nashe may have habitually frequented the Southwark taverns of Flemish brewers such as Peter "Pickle-herring” Van Durant.

Even before around 1610, when the stage clown created in Germany by the English actors was formally named Pickelhering, many English literary usages linked the term to Southwark associations of heavy social drinking. In the writings of Harvey, Rowlands, Dekker, Marlowe and Shakespeare, the term "pickle(d) herring(s)" alludes not simply to the fish, but also to the sinful gluttony and clownish, red-nosed, boisterous folly of the heavy drinkers in Southwark's Pickle Herring district, and the Dutchmen who provided its beer and Flemish pickle-herrings. A chain of historical evidence links the culinary use of the term "pickled herring"-via late sixteenth-century allusions to drinking associations in an area close to London's Globe Theatre-to its seventeenth-century theatrical use on mainland Europe as the name of the comic stage clown Pickelhering. A persuasive new link in this chain is provided by Peter van Durant's will of 1584. Sustained mockery of Robert Greene's death from too much alcohol and pickled herring, by Gabriel Harvey and other writers, ensured that van Durant's nickname sealed Southwark's legendary reputation: for extremes of alcoholic excess that were sinful-sometimes even fatal. In short, this reconsideration of the term "Pickelhering" provides valuable contextualisation for its choice as a comic stage name by the English actors in early seventeenth-century Northern Europe, by confirming its establishment as a popular London nickname in the 1580s.

The commedia dell'arte's international stars generated pan-European interest. A possible influence on the English actors' choice of Pickelhering is the success of an earlier fish-inspired stage name, Stefanelo Botarga, whose Italian creator acted mainly in Spain. A German festival book recording a Düsseldorf court wedding of 1585 suggests both the extent of the late sixteenth-century German fashion for Italian commedia dell'arte performances at court weddings

32 Dekker, A knights Coniuring, sig. Lr.

33 Samuel Rowlands, The Letting of Hvmovrs Blood in the Head-Vaine: With a new Morissco, daunced by seauen Satyres, vpon the bottome of Diogines Tubbe (London: W[illiam] F[erbrand], 1600), Satyre 6, sigs. E6r-E8r, sig. E8r. 
and the unprecedented impact of Botarga. ${ }^{34}$ Because of their linguistic barriers and unpredictable weather conditions, the German-speaking regions were an unattractive commercial prospect for speculative tours by anything larger than modest Italian troupes of the type supporting charlatans and quack doctors. This ensured that, North of the Alps, full-strength mixed-gender Italian troupes of upwards of ten players, performing full-length commedia dell'arte plays, represented a prestigious badge of international cultural sophistication, limited to the wealthiest and most highly educated patrons. German noblemen unable to afford the status symbol of inviting full-strength Italian troupes to their courts found other ways of incorporating elements of the commedia dell'arte into their festivals.

On Tuesday 18 June 1585, guests enjoyed a costumed running at the ring, staged at the Düsseldorf court of Duke Wilhelm von Jülich, Cleve and Bergen, during the third of eight days of festivities for the marriage of his heir, Prince Johann Wilhelm, to Princess Jakobine von Baden. ${ }^{35}$ Eight of the nine competing groups of knights chose to wear nationally or classically inspired masquerade costume such as that of Moors or Persians, mermaids or Amazons. Drawing on very recent developments in Italian professional acting, the ninth tournament group caused something of a sensation through its novel choice of stage costume, and specifically that of the central comic master-servant pair of the commedia dell'arte, the elderly Venetian Magnifico, and his rustic servant, Zanni. While the festival book of the 1585 Düsseldorf wedding does not depict the commedia dell'arte group as such, it does depict the parade that opened their tournament. According to its text, the six knights of the ninth group entered in two rows. Three knights in front were costumed in the red underclothes, red berets and black cloaks worn by the commedia dell'arte masters; three knights behind them were costumed in the unbleached wide cut sailor trousers of their servants. Such masquerade groups were typically mounted on thoroughbred horses, led by court musicians playing military instruments such as drums or trumpets. But this group had more surprises for their judges and audience. They entered perched on

34 Dietrich Graminaeus, Beschreibung derer Fürstlicher Güligscher [e]tc. Hochzeit so im jahr Christi tausent fünffhundert achtzig fünff am sechszehenden Junij vnd nechstfolgenden acht tagen zu Düsseldorff mit grossen freuden, Fürstlichen Triumph vnd herrligkeit gehalten worden (Cölln: [Gras], 1587).

35 The ninth tournament entry is described on sigs. Pv-Rr. Alberto Martino partially transcribes sigs. Q2r-v ("Fonti tedesche degli anni 1565-1615 per la storia della Commedia dell'arte e per la costituzione di un repertorio dei lazzi dello Zanni," in: Martino and Fausto de Michele, eds., La ricezione della Commedia dell'Arte nell'Europa centrale 1568-1769: Storia, testi, iconografia [Pisa/ Roma: Serra, 2010], pp. 13-68, p. 17). 
donkeys loaded with bales of hay, led by two professional actors, Italian buffoni costumed as a Venetian Magnifico and his servant, Zanni. The six suspiciously foreign-looking knights completed the formalities of tournament greetings, including an unusually lengthy interrogation by the judges, before being permitted to compete at the running of the ring. Meanwhile, the two Italian professional actors entertained the spectators with all manner of comic routines, or lazzi, of the commedia dell'arte. Some mocked chivalrous customs, such as the accepted ways of mounting and dismounting a tournament horse, others relied heavily on singing and acrobatics, in which, the official record of this court festival here assures us, the Italians excel "above all other nations.” While the Venetian Magnifico played tricks with his cloak, the Zanni kept altering his "strange, large hat [...] in different ways." ${ }^{36}$ The duo also sang comic Italian songs to a viola and played numerous ridiculous tricks with a rustic farmyard rake or harrow, of a type illustrated in the central vignette of a late sixteenth-century print by Ambrogio Brambilla depicting nine lazzi. ${ }^{37}$

Although Diederich Graminaeus, author of the official published festival book, does not name the two Italian professionals within its description of their performance, he does identify each of the six German knights in this masquerade both by their own name and by their chosen stage name:

Otto Wildt Rheingraff / so sich Tofano Dacon Gentelomo de Venetia, Herr Carl Graff zu Zollern / Stephanello putarcho Il Consilier dela signioria de Venetia, Herr Philips Marckgraff zu Baden un[d] Hochberg, Pantalion de Bisoignosi gentilomo de Venetia. Die drey folgende aber / Herr Jacob Marckgraff zu Baden / Il Senior Petrolin. Der Edler und Ehrenfester Niclaß Pickadel / Il Senior Ioan Carotta, auch Albrecht Thuen / so sich Il Senior Rauanel genant. ${ }^{38}$

Graminaeus here indicates that the masquerade was organised by one of the knights riding in the front row, the then 38-year-old Duke Karl von Hohenzollern (1547-1606). Elsewhere, he lists the complete entourages of all the major wedding guests, and provides a possible identification for the professional buffoni, as the two servants named as: "Jacob the Italian and his companion" in the entourage of the bride's brother, Karl's distant relative Margrave Philip. ${ }^{39}$ As well as Philip, Karl's group included a second Catholic Margrave of Baden, his first cousin Jacob,

36 See Graminaeus, Beschreibung, sigs. Q2r-v; my translation ("einem seltzamen grossen Huth / denselben er mit vielfeltiger enderung zu gebrauchen gewist [...] Haben sich auch mit singen und springen erzeigt / wie dann vor allen anderen sich alsolche Nation einzustellen weiß / den Preiß zuerhalten").

37 Reproduced in Katritzky, The Art of Commedia, p. 395, plate 54.

38 Graminaeus, Beschreibung, sigs. Qr-v; emphasis in the original.

39 Sig. C5v ("Jacob der Welß und sein gesellen"). 
whose entourage included this masquerade's three remaining noblemen: Jacob's chief steward, Claß von Pickadel, Albrecht Thun von Newburg and Rheingraf Otto zu Kyrburg, brother of Duke Karl's future daughter-in-law Juliane Ursula von Salm. ${ }^{40}$ Philip took the generic name of the old master, or Venetian merchant, of the commedia dell'arte (Pantalon) and Jacob the stage name of one of its most successful servants (Pedrolino). The remaining three knights who accompanied Karl took the stage names of a commedia dell'arte master (Tofano) and servants (Zan Carotta, Zan Ravanel) whose originators are unknown, although they are named in playtexts and popular publications of the time. ${ }^{41}$ Graminaeus's interpretation of this masquerade refers to virtuous government, while hinting at a distaste for professional performers and revealing that the three knights who took the parts of the comic servants were costumed in "variously coloured clothes, including red caps and grey hats which they liked to keep changing and altering into different shapes, according to their preference." 42

Duke Wilhelm of Bavaria, first cousin of Margrave Philip, chose Duke Karl to represent him at the 1585 Düsseldorf wedding. ${ }^{43}$ In 1568 , both Karl and his father were present at the festivities for Wilhelm's own wedding, at the Munich court of his father. Karl was then a trusted twenty-year-old Munich courtier. Duke Karl's father, who from the age of 12 grew up at the Madrid court of his godfather,

40 See Katritzky, Healing, Performance and Ceremony in the Writings of Three Early Modern Physicians: Hippolytus Guarinonius and the Brothers Felix and Thomas Platter (Farnham/Burlington, VT: Ashgate, 2012), p. 343 (Diagram 2b).

41 Tofano is a stock role of commedia dell'arte scenarios (e.g., Flaminio Scala, Il Teatro delle Fauole rappresentatiue, overo La Ricreatione Comica, Boscareccia, e Tragica: Divisa in Cinquanta Giornate [Venezia: Pulciani, 1611], Day 24: “Il Finto Tofano," pp. 69-71). Sixteenth-century texts naming Zan Carotta and Ravanel transcribed by Vito Pandolfi (La Commedia dell'Arte: Storia e testo, ed. Vito Pandolfi, 6 vols. [Firenze: Le Lettere, 1957-1961]) include, for both: Il Lachrimoso Lamento che fe Zan Salcizza, e Zan Capella, Inuitando tutti i Filosofi, Poeti, e tutti i Fachi delle ualade, à pianzer la morte di Zan Panza di Pegora, alias Simon Comico Geloso (Venezia: Al Segno della Regina, 1585) (in: La Commedia dell'Arte, vol. 1, pp. 219-226); Opera nuova Nella quale si contiene vno insonio, che ha fatto il Zanni Bagotto, in lingua Bergamasca (s.l., 1576) (in: La Commedia dell'Arte, vol. 1, pp. 257-261); Bartolomeo Rossi, Fiammella Pastorale (Paris: Abel L'Angelier, 1584) (in: La Commedia dell'Arte, vol. 2, pp. 96-120, p. 113); for Ravanel only: Pronostico nvovo sopra l'anno presente, composto per il vostro amoreuolissimo Missier Rauanel Astrologo Bergomensis (Venezia: In Frezzaria al Segno della Regina, 1581) (in: La Commedia dell'Arte, vol. 1, pp. 205-208).

42 Graminaeus, Beschreibung, sig. Ee2r; my translation (“[...] in underscheidlicher farben Kleidung / als mit roden Kappen, / grawen Hühten die man offtermahl nach wolgefallen in vielfeltiger gestalt enderen und umbwechselen möchte [...].”); sig. Ee3v.

43 Sigs. Dv-D2r. 
Emperor Charles $\mathrm{V},{ }^{44}$ was the guest of honour in Munich, representing King Philip II of Spain. The 1568 wedding festivities included comic interludes performed by Italian buffoni, and the earliest substantially documented commedia dell'arte performance. This was staged by Munich court musicians, including the renowned Flemish choir master Orlando di Lasso as the Venetian Magnifico and the Neapolitan tenor singer Massimo Troiano as his servant Zanni. ${ }^{45}$ The commedia dell'arte performances of the 1568 Munich wedding evidently made a deep and lasting impression on Duke Karl. They influenced his choice of commedia dell'arte masquerade costumes in 1585, and again in 1598. Karl's 1598 masquerade costumes, wrongly described as specific types of regional costume in Jakob Frischlin's court-sponsored printed festival book description, ${ }^{46}$ are correctly identified as those of various commedia dell'arte servants by Felix Platter, who attended the 1598 festival in his capacity as court physician to the bride's brother-in-law. ${ }^{47}$ Platter's account reveals that, costumed as Zan Badello, Duke Karl organised a tournament entry of ten knights, including himself, all costumed as variants of the Zanni, or comic commedia dell'arte servant. The only participant of Karl's 1585 masquerade who also joined him at the 1598 tournament was Reingraf Otto. Duke Karl had abducted his future wife, Jacob of Baden's widow, in 1590, and by 1598, Philip of Baden had also died.

In 1585, Duke Karl masqueraded not under the name of a commedia dell'arte servant, but a Venetian master, Stephanello Putarcho. Successful Italian commedia dell'arte actors typically specialised for many years in one part, often played under their own personal stage name. The stage name Stefanelo Botarga was created by the Italian professional actor Abagaro Frescobaldi, whose father was a Florentine merchant resident with his family in Padua at his birth. His three sisters were aged 32, 26 and 24 years old at their father's death around 1568, suggesting birth dates for Abagaro and his brother during the 1530s or 1540s. Frescobaldi was already using the stage name Botarga by the time of his earliest recorded performances, in Padua in 1568 and $1571 .{ }^{48}$ He toured Iberia with his

44 Ernst Georg Johler, Geschichte, Land-und Orts-Kunde der souverainen teutschen Fürstenthümer Hohenzollern, Hechingen und Sigmaringen: Beiträge zur Geschichte von Schwaben (Ulm: Stettin, 1824), pp. $48 \mathrm{f}$.

45 Katritzky, The Art of Commedia, pp. 54-58.

46 Jakob Frischlin, Drey schöne und lustige Bücher von der Hohenzollerischen Hochzeyt [1599], ed. Casimir Bumiller (Konstanz/Eggingen: Isele, 2003), pp. 222 f., p. 240.

47 Felix Platter, Tagebuch: (Lebensbeschreibung) 1536-1567, ed. Valentin Löscher (Basel/ Stuttgart: Schwabe, 1976), pp. 499-501. On the 1598 masquerade, see also Katritzky, The Art of Commedia, p 47, pp. 96-102; Katritzky, Healing, Performance and Ceremony, pp. 117-126.

48 María del Valle Ojeda Calvo, "Otro manuscrito inédito atribuible a Stefanelo Botarga y otras noticias documentales,” Criticón 92 (2004), pp. 141-169, p. 144, p. 165. 
own troupe in the 1580s, and before that with the renowned commedia dell'arte troupe of the Roman actress Barbara Flaminia and her husband Alberto Naseli of Ferrara, who respectively performed under the stage names Hortensia and Zan Ganassa. ${ }^{49}$ In the late 1560 s, Flaminia was the star of her troupe, staging competitive performances at the court of Mantua with the troupe of her great rival, Vincenza Armani..$^{50}$ In 1568, the two troupes amalgamated and Flaminia left to join the troupe of Naseli, whose comic performances were also attracting considerable attention by 1570, when he and an actor playing the Spaniard Ernandico entertained guests at a court wedding in Ferrara by engaging in a mock battle at the end of a banquet. ${ }^{51}$ A treatise of 1634 on acting, by the commedia dell'arte actor Nicolò Barbieri (stage name: "Beltrame”), includes Arlecchino and Ganassa among its rare named references to contemporary performers: "La Spagna prima si seruiua delle nostre Italiane, e i Comici vi faceuauo assai bene: Arlicchino, Ganaßa \& altri hanno seruito la felice memoria di Filippo secondo, \& si fecero ricchi; ma doppo quel Regno ne hà partorito tante, che ne riempie tutti quei gran Paesi, \& ne manda anche molte Compagnie in Italia."52 Fifteen years later, in 1649, Giovan Domenico Ottonelli quotes this passage in a section of his lengthy theatrical treatise. Unfavourably comparing Italian with Spanish actors, he notes here that Barbieri told him that during a visit of 1644 to Florence a Florentine had passed on first-hand reports of Ganassa's troupe that he had heard around the year 1610, from older Spanish colleagues in Seville who (although Lope de Vega celebrates Ganassa's bawdy lazzi $)^{53}$ expressly praised the Italian troupe for its uncharacteristic lack of obscenity:

49 Ojeda Calvo, Stefanelo Botarga e Zan Ganassa: Scenari e zibaldoni di comici italiani nella Spagna del Cinquecento (Roma: Bulzoni, 2007), pp. 85-90.

50 Katritzky, The Art of Commedia, p. 86, p. 201, p. 246.

51 Angelo Solerti and Domenico Lanza, "Il teatro ferrarese nella seconda metà del secolo XVI," Giornale storico della letteratura italiana 18 (1891), pp. 148-185, p. 159; Robert Henke, Performance and Literature in the Commedia dell'Arte (Cambridge/New York: Cambridge University Press, 2002), p. 83.

52 Nicolò Barbieri, La Svpplica: Discorso famigliare [...] Diretta a quelli, che scriuendo, ò parlando trattano de' Comici (Venetia: Marco Ginammi, 1634), p. 80-81. Despite continuing confusion on this issue, it seems most unlikely that Naseli ever played the role of Harlequin, which was first developed by Tristano Martinelli (on this point, see also Maria Grazia Profeti, “Ganassa, Bottarga e Trastullo in Spagna,” in: Anna Maria Testaverde and Alberto Castoldi, eds., Zani Mercenario della Piazza Europea: Giornate Internazionali di Studio, Bergamo 27-28 Settembre 2002 [Bergamo: Moretti \& Vitali, 2003], pp. 178-197, pp. 181 f.).

53 Norman D. Shergold, "Ganassa and the 'Commedia dell'Arte' in Sixteenth-Century Spain," Modern Language Review 51 (1956), pp. 359-368, p. 363. 
[...] Ganassa, Comico Italiano, e molto faceto ne' detti, andò là con vna Compagnia di Comici Italiani, e cominciò à recitare all'vso nostro: e se bene egli, come anche ogni altro suo compagno, non era bene, e perfettamente inteso, nondimeno con quel poco, che s'intendeua, faceua ridere consolatamente la brigata; onde guadagnò molto in quelle Città, e dalla pratica sua impararono poi gli Spagnuoli á fare le Comedie all'vso Hispano, che prima non faceuano. Tutto questo io accetto per vero, e credo, che, come Ganassa cercaua di apportar vtile, e diletto co' suoi gratiosi motti, e recitamenti priui di oscenità, così gli Spagnuoli impararono à fare Comedie modeste, e non oscene. ${ }^{54}$

Naseli and Flaminia's troupe consolidated the fashion for commedia dell'arte at German court weddings, tentatively pioneered in Munich in 1568, by performing at the imperial Habsburg wedding festivals of 1570. Having played at the 1570 Prague proxy wedding festivities for Emperor Maximilian II's daughter Anna, to Philip II, they followed Anna's sister Elisabeth, betrothed to Charles IX, to Paris; performing en route at her proxy wedding festivities at the imperial Diet of 1570 in Speyer. ${ }^{55}$

Frescobaldi, possibly already with Naseli's troupe for up to three years when Philip II called them from Paris to Madrid in 1574, was touring Iberia with them by 1574 . When he played Stefanelo Botarga to Naseli's Zan Ganassa, the duo created an immensely popular master-servant double act, celebrated in and beyond Spain. Diverse textual and visual records of Frescobaldi, with or without Naseli, include a madrigal referring to "Zanni o Stefanello" by Antonfrancesco Grazzini ("Il Lasca," 1503-1584), ${ }^{56}$ Adriano Banchieri's "Stefanello Botarga Chiozotto, mercante da fichi secchi" of $1601,{ }^{57}$ the Venetian merchant "Stefanel" or "Stefanel Bottarga" in Flaminio Scala's scenari collection of 1611,58 and

54 Giovan Domenico Ottonelli, Della Christiana Moderatione del Theatro Libro Secondo, detto La Solvtione de' Nodi (Firenze: Gio. Antonio Bonardi, 1649), p. 37.

55 Armand Baschet, Les comédiens italiens à la Cour de France sous Charles IX, Henri III, Henri IV et Louis XIII d'après les lettres royales, la correspondance originale des comédiens, les registres de la trésorerie de l'épargne et autres documents (Paris: Plon, 1882), pp. 24 f., pp. 41 f.; Karl Trautmann, "Italienische Schauspieler am bayerischen Hof," Jahrbuch für Münchener Geschichte 1 (1887), pp. 193-312, pp. 228-230; Otto G. Schindler, “Comici dell'Arte bereisen Europa: Ein Abriss,” Maske und Kothurn 50.3 (2005), pp. 7-17, p. 9; Schindler, “Comici dell'Arte alle Corti austriache degli Asburgo," in: Martino et al., eds., La ricezione della Commedia dell'Arte, pp. 69-143, pp. 73-87.

56 Antonfrancesco Grazzini, Le Rime Burlesche edite e inedite, ed. Carlo Verzone (Firenze: Sansoni, 1882), p. 297 (Madrigal 33, v. 25); Kathleen Marguerite Lea, Italian Popular Comedy: A Study in the Commedia dell'Arte, 1560-1620, with Special Reference to the English Stage, 2 vols. (Oxford: Clarendon Press, 1934), vol. 1, p. 250.

57 See Ojeda Calvo, Stefanelo Botarga e Zan Ganassa, p. 142.

58 Scala, Il Teatro delle Fauole rappresentatiue, Days 23: "Il Portalettere," pp. 66-68, and 27: “La Mancata Fede,” pp. 78-81; Lea, Italian Popular Comedy, vol. 2, p. 482. Possibly influenced by Botarga are various references to the old Venetian master "Stefano caragolo Venetiano," by 
popular prints featuring "Pantalone and Stefanello" 59 or, in the Recueil Fossard, "Stephanel Bottarga." 60 From 1581 onwards, Frescobaldi’s impact on Iberian performance practice became even more direct. Naseli and Flaminia continued touring Spain until they returned to Italy in $1584 .{ }^{61}$ In 1581, instead of following them to Madrid, Frescobaldi married the newly widowed Spanish actress Luisa de Aranda, and took the place of her late husband, Juan Granado, co-leading Aranda's Spanish acting troupe around Valladolid, Valencia, Madrid and Seville. The latest records cited in connection with the couple's activities date to 1588 in Spain and Frescobaldi's signature is said to be absent from a lost document of 1604 recording Aranda's sale of the family home in Valladolid, leading Ojeda Calvo to suggest that she was then already a widow. ${ }^{62}$ However, a record that has escaped attention in this context possibly indicates that Frescobaldi's career continued into the seventeenth century, outside Spain, where the commercial theatres were closed down completely in the late 1590s, before being permitted to reopen in 1600, with even greater restrictions on actresses. Jean Héroard, personal physician to Louis XIII, records that for a week or so after seeing the Accesi, the Mantuan court troupe of Italian professional actors, perform at Fontainebleau in August 1608, the then seven-year-old French Dauphin selected his daily palace password from their stage names. Having already chosen the names Fritellino and then Pantalone:

Le 15 [August 1608], vendredi [...] Il donne pour mot du guet: Colo, c'étoit le nom de l'un des comédiens. [...] Le 17 [...] [I]l donne pour mot du guet: Doctor, personnage de la comédie. Le 18 [...]. [I]l donne le mot Piombino, qui étoit un comédien. Le 19, mardi [...]. Il donne pour mot Stefanello, après s’être fait nommer tous ceux qu'il avoit donnés les jours précédents. ${ }^{63}$

his servant "Zan Buratino Bergamasco," as "M. Strofanel," "M. Stronfanel” or "M. Stefanello" in a play of 1613 by Giovanni Sinibaldi (Gl'otto assortiti comedia: Nova, piacevole, \& ridicolosa [Venetia: Giovanni Alberti, 1613], fol. 28r, fols. 34r-v, fol. 44v, fol. 47r).

59 Katritzky, The Art of Commedia, p. 596, plate 308 (Il Trionfo de Carnavale nel paese de Cucagna). 60 Pierre Louis Duchartre, The Italian Comedy (New York: Dover, 1966), p. 333 (Recueil Fossard 36).

61 Bernardo José García García, "L’esperienza di Zan Ganassa in Spagna tra il 1574 e il 1584," in: Testaverde et al., eds., Zani Mercenario della Piazza Europea, pp. 131-155, pp. 134-136, p. 143. 62 "Otro manuscrito inédito atribuible a Stefanelo Botarga," p. 165; Ojeda Calvo, Stefanelo Botarga e Zan Ganassa, pp. 89 f.

63 Journal de Jean Héroard sur l'enfance et la jeunesse de Louis XIII (1601-1628), eds. Eudore Soulié and Edouard de Barthélemy, 2 vols. (Paris: Firmin Didot, 1868), vol. 1, pp. 351-353 (see also Baschet, Les comédiens italiens, pp. 182-184 and Lea, Italian Popular Comedy, p. 281, p. 482). 
Either Frescobaldi's stage name had already been taken over by a younger Italian professional by $1608,{ }^{64}$ or he himself was then touring France with the Accesi troupe.

One trademark characteristic of commedia dell'arte performances is their mastery of improvisation. Many commedia dell'arte actors based their pre-rehearsed improvised speeches on memorable dialogue. The best actors collected, wrote down and memorised useful texts in personal notebooks known as zibaldoni. Two manuscripts, variously written in the Venetian dialect, maccaronic Latin, Spanish or Catalan, recording a wealth of texts of particular relevance to the commedia dell'arte Venetian merchant were discovered in the 1990s in the Royal Library of Madrid and identified as being compiled by Frescobaldi during the 1580s, by María del Valle Ojeda Calvo, who published her edition of one of them in $2007 .^{65}$ As the only known zibaldoni belonging to a commedia dell'arte actor in the role of the old master, Frescobaldi's manuscripts provide valuable insights into typical "improvised" speeches of the Pantalone figure, which they refer to by various names, including "Stefanello" and "Botarga." A major source for Frescobaldi's zibaldoni is Andrea Calmo's comic Lettere (already plundered by dramatists such as Giovan Battista Cini and Domenico Bruni); others include political writers such as Macchiavelli or Castiglione, playwrights such as Ludovico Dolce or Giovan Battista Giraldi, and Spanish writers such as Melchior de Santa Cruz or Diego Hurtado de Mendoza. ${ }^{66}$ Ojeda Calvo cites Cesare Rao as a possible influence on the "second-hand erudition" of such "literary piracy," identified by her as the dominant working method not just of Botarga, but of early modern commedia dell'arte actors as a whole. ${ }^{67}$ Rao is the editor of the only known text outside Botarga's own zibaldone associated with the actor, a comic lament to Ganassa's loss of his friendship with a deceased louse published in 1585. This

64 The actor Giovan Giorgio is thought to have revived the role of Ganassa on the Spanish professional stage from 1592 to 1603 (Jaime Sánchez Romeralo, "El supuesto retorno de Ganassa a España,” Quaderni ibero-americani 67-68 [1990], pp. 121-131; Profeti, “Ganassa, Bottarga e Trastullo," p. 179).

65 Ojeda Calvo, Stefanelo Botarga e Zan Ganassa ("Lo zibaldone di Stefanelo Botarga [Ms. II1586],” pp. 181-590).

66 Ojeda Calvo, “Stefanelo Botarga: un pirata della letteratura," in: Testaverde et al., eds., Zani Mercenario della Piazza Europea, pp. 156-177, p. 157, pp. 164 f.; Ojeda Calvo, "Otro manuscrito inédito atribuible a Stefanelo Botarga,” pp. 144-147, p. 154; Ojeda Calvo, Stefanelo Botarga e Zan Ganassa, pp. 113-129, pp. $168 \mathrm{f}$.

67 Ojeda Calvo, "Stefanelo Botarga: un pirata della letteratura," pp. 171 f.; Ojeda Calvo, Stefanelo Botarga e Zan Ganassa, pp. 124 f., p. 140. 
"Lament of Ganassa and Botarga" (on the death of a louse) ${ }^{68}$ confirms the two roles as variants of the Italian professional stage's central servant-master pair and offers a particularly clear example of the "plagiarised literary collage" and wide literary reading required to underpin and refresh their improvised dialogue. A recycled update of Ortensio Lando's burlesque “Oratione di Puccio nella morte d'un suo pedocchio" (first published in Venice in 1549, in Sermoni funebri de' vari authori nella morte de diversi animali), its ultimate classical sources most notably include Lucian of Samosata's consummate Greek exercise in Menippean parody, Encomium of the Fly, widely celebrated via Leon Battista Alberti's ironic Renaissance Latin mediation, Musca. ${ }^{69}$

Pastoral and satiric fragments based on classical sources feature heavily in Frescobaldi's zibaldoni; religious plots and characters, beyond one mystery play fragment and a dramatised Ave Maria, hardly at all. ${ }^{70}$ This amply bears out the complaints of two Spanish Jesuits whose anti-theatrical attacks, approvingly citing attempts by the early Christian fathers to have actresses banned from Rome, appear to target the activities of Naseli's troupe. In 1593, liberally quoting early churchmen, Pedro de Ribadeneyra, who accompanied Philip II to England during his marriage to Mary Tudor in the 1550s, condemns:

[...] estas representaciones, Pestilencia de la republica[,] [...] Catedra de pestilencia, escuela de incontinencia; obrador de luxuria; horno de Babylonia[,] [...] Fiesta delos demonios[,] [...] inuencion del demonio, para corromper y destruyr el genero humano. En otra, [...] compara[n]do el teatro (q[ue] es lugar de las representaciones) con la carcel [...]. [...] Grandes males hazen las comedias en las ciudades [...]. [...] [L]as mugercillas que representan comunme[n]te son hermosas, lasciuas, y que han vendido su honestidad, y co[n] los meneos y gestos de todo el cuerpo, y con la boz bla[n]da y suaue, con el vestido y gala a manera de Sirenas, encantan, y transforma[n] los hombres en bestias [...]. ${ }^{71}$

In 1589, Juan de Pineda accuses foreign comedians, "especially the Italians," of provoking Spaniards to great sinfulness by rejecting the opportunity to showcase virtuous Catholic saints such as Catherine, Agnes or Lucy, in favour of plots

68 Cesare Rao, L'argvte, et facete lettere:[...] Nelle qvali si contengono molti leggiadri Motti, \& solazzeuoli Discorsi (Trento: Marc’Antonio Pallazzolo, 1585), fols. 98r-99r ("Lamento di Giovanni Ganaßa, con M. Stefanello Bottarga suo Padrone”); Shergold, "Ganassa and the 'Commedia dell'Arte'," p. 363; Henke, Performance and Literature, p. 83.

69 On which, see Jean-Claude Margolin, "L'influence de Lucien sur les 'Propos de table' d'Alberti,” Revue belge de philologie et d'histoire 51.3 (1973), pp. 582-604, p. 587, pp. 598-604.

70 Ojeda Calvo, "Nuevas aportaciones al estudio de la Commedia dell'arte en España: el zibaldone de Stefanello Bottarga,” Criticón 63 (1995), pp. 119-138, p. 123.

71 Pedro de Ribadeneyra, Tratado de la Tribvlacion: Repartido en dos libros (Alcalá: Iuan Iñiguez de Lequerica, 1593), fols. 63r-64r, fol. 70v. 
based on classical pagans such as "Medea and Jason, Paris and Helen, Aeneas and Dido, and Pyramus and Thisbe."72

Pineda's references to classical pastoral lend added weight to an account of Ganassa which has largely escaped the attention of theatre historians, although musicologists cite it as exemplifying the professional musician Domenico Pietro ("Pedro") Cerone of Bergamo's first-hand and anecdotal knowledge of "Peninsular theorists and practitioners."73 Having spent around a decade in Spain, in 1603 Cerone (c. 1566-1625) was appointed musician to the court of Naples and priest at the church of SS. Annunziata. Here he finalised his weighty treatise on music; aligned with moralising didactic Counter-Reformation principles and dedicated to Philip III, it was published in Castilian, for Spanish Empire readership, in $1613 .{ }^{74}$ An early section, explaining that those who abuse music do not deserve to be called musicians, opens with a consideration of Ganassa, a troupeleader known to have hired local musicians while in Catalonia. ${ }^{75}$ Here, Cerone offers valuable insights into the stage practice of the troupe with which Frescobaldi toured Iberia during the 1570s, confirming the importance of pastoral music, singing and dancing in their performances, their use of rustic instruments such as hurdy-gurdies, and the judgmental distaste with which church and court musicians then viewed the commercial stage-based activities of "such wild musicians":

No ay Sacristan ni moço de Choro, que de buena gana no affeyte con el honroso titulo de Musico. Este mal vso vino à notar Ganassa comediante Italiano, quando en las postreras comedias, que recitò en la ciudad de Barzelona en Cataluña, representò vna Pastoral; adonde entre los otros diuersos personajes, introduxo à vnos pastores que dançauan, otros que tañian la gayta, y otros instrumentos rusticos, y à otros que cantauan à su Dios versos de alabança: y entre ellos auia vn porquero, que tañia vn cuerno, el qual discurendose quien lo auia hecho mejor, dixo: Nosotros los Musicos merecemos guirlandas texidas por mano del nuestro PAN. Por cierto grande bofetada diò entonces Ganassa à los Cantores de oydia, que tan facilmente se vsurpan el nombre de Musico; introduziendo en su comedia vn vil porquero tañedor de cuerno, que tan desuergonçadamente se vsurpasse el nombre

72 Juan de Pineda, Primera parte de los treynta y cinco dialogos familiares de la Agricvltura Christiana (Salamanca: Pedro de Adurça, y Diego Lopez, 1589), fols. 349v-350r (Dialogo 15, para.26), fol. 350r; my translation ("especialmente de los Italianos"; "[gozando de los cuentos] de Medea y de Iason, y de Paris y Helena, y Eneas y Dido, y de Piramo y Tisbe [...]”).

73 Robert Stevenson, “[Review:] El Melopeo Tractado de Musica Theorica y Practica by Pedro Cerone," Journal of the American Musicological Society 24.3 (1971), pp. 477-485, pp. $480 \mathrm{f}$.

74 Enrique Alberto Arias, “Cerone as Historian,” Anuario Musical 58 (2003), pp. 87-110, pp. 89 f. 75 As recorded, for example, in his contract of 1581 with two Castilian musicians (John V. Falconieri, “Historia de la 'Commedia dell'Arte' en España,” Revista de Literatura 11 (1957), pp. 3-37 \& 12 (1958), pp. 69-90, p. 26; Shergold, “Ganassa and the 'Commedia dell'Arte'," p. 362; García García, “L’esperienza di Zan Ganassa in Spagna,” p. 138, p. 150). 
de Musico. Paresceme que à tal termino à llegado este mal vso, que solo falta, que estos iñorantes se pongan en comunidad con los virtuosos Maestros y eccelentes Musicos; y que en sus conuersaciones y platicas salgan con vn preambulo de Nosotros Musicos: ygualando el cantar del cueruo, al del ruynseñor: y comparando el faber del torpe asno, al de la prudente y sabia raposa. ${ }^{76}$

Cerone's disapproval of professional actors, and concern to distance the emerging professions of music from the distinctively costumed Italian actors in Spain, resurfaces a few pages further on. Here, he emphasises that true musicians reject deforming acrobatics, vanities and fooling, and especially strange costumes of the type which, according to St Bernard, indicate bad practice. ${ }^{77}$

Stefanelo Botarga's influence persisted far beyond his own period. The pimento red costume of the botarga features repeatedly in the poetry of Francisco de Quevedo y Villegas. ${ }^{78}$ Several of Lope de Vega's writings allude to Ganassa and Estefanelo or Botarga. Botarga costume is worn as a stock Spanish festival disguise in his play Las ferias de Madrid ${ }^{79}$ and throughout the seventeenth century, and at least once by the great playwright himself. At the 1599 double wedding of the recently deceased Philip II's son, King Philip III of Spain, to Margarita of Austria, and Philip III's sister Isabella to Margarita's cousin, Albert of Austria, Lope de Vega, in his Botarga costume and mounted on a mule laden with meat, himself symbolised Carnival. Lent was represented by his servant, carrying fish and wearing a turban hung with eels and sardines. ${ }^{80}$

Food was a major source for comic stage names and it is worth examining Botarga and Pickelhering in the context of the foods that gave them their names: the North Sea fish speciality Bückelhering and the Mediterranean fish speciality

76 Domenico Pietro Cerone, El Melopeo y Maestro, tractado de mvsica theorica y practica: en que se pone por extenso, lo que vno para hazerse perfecto Musico ha menester saber[,] [...] repartido en XXII Libros (Napoles: Iuan Bautista Gargano y Lucrecio Nucci, 1613), Libro primero, chap. 22: "De como ay vnos que se vsurpan el nombre de Musico, no siendo meriteuoles del nombre de Cantor,” pp. 64-66, pp. $64 \mathrm{f}$.

77 Libro primero, chap. 28 "Quales condiciones ha de tener el buen Maestro,” pp. 74 f., p. 75.

78 Francisco Gómez de Quevedo y Villegas, Poësias de Don Francisco de Quevedo Villegas, [...] Tercera Parte (Brusselas: Francisco Foppens, 1670), p. 281 (Thalia, Musa sexta, soneto 53: "Burlase del Camaleon, moralizando satiricamente su naturaleza"), p. 338 (Thalia, Musa sexta, romance 17: "Los Borrachos celebres," pp. 337-339), p. 448 (Thalia, Musa sexta, romance 88: "Matraca de los Paños, y Sedas,” pp. 443-449), p. 449 (Thalia, Musa sexta, romance 89: "Pavura de los Condes de Carrion,” pp. 449-451).

79 Félix Lope de Vega y Carpio, Segvnda Parte de las Comedias de Lope de Vega Carpio (Valladolid: Iuan de Rueda, 1611), fols. 334r-365v, fol. 362v.

80 Shergold, “Ganassa and the 'Commedia dell'Arte',” pp. 363-366; Valls, "La representación y la interpretación,” pp. 259 f.; Profeti, “Ganassa, Bottarga e Trastullo,” pp. 185 f. 
botargo. Joseph Addison, writing in 1711 about food-based stage names, recognised their national significance as an important aspect of their comicality, writing of stage clowns:

[T] here is a Set of merry Drolls, whom the common People of all Countries admire [...]: I mean those circumforaneous Wits whom every Nation calls by the Name of that Dish of Meat which it loves best. In Holland they are termed Pickled Herrings; in France, Jean Pottages, in Italy, Maccaronies; and in Great Britain, Jack Puddings. These merry Wags, from whatsoever Food they receive their Titles, that they may make their Audiences laugh, always appear in a Fool's Coat, and commit such Blunders and Mistakes in every Step they take, and every Word they utter, as those who listen to them would be ashamed of. ${ }^{81}$

This pragmatic early eighteenth-century approach, associating the origins of food-based clown names with favourite national dishes, or with culinary practices during Carnival and Lent, is still broadly accepted by most modern theatre specialists. According to Ralf Haekel, for example, "Most clown names signify foods." "Pickelhering derives from the English 'pickled herring,' that is from preserved herrings." 82

Let me complicate this a little by proposing another, rather more speculative, influence that, by contrast, has received little or no attention in this context. It concerns what I refer to as "literary anthropologies": preserved and modified cultural memories of paraethnographic records such as the descriptions of monstrous or marvellous foreign races recorded by the classical writers Alexander the Great and Pliny. ${ }^{83}$ Literary anthropologies supplied a template for the expectations of colonial explorers deep into the seventeenth century. Early modern Europeans were intensely aware not just of their own continent, but of the startling expansion of the known world into new continents undocumented by Biblical or classical sources. Rather than viewing these new discoveries with fresh eyes, their expectations of New World inhabitants were profoundly shaped by literary anthropologies. The map of the New World in the 1561 edition of Sebastian Münster's great cosmography of the whole known world, first published in 1552, hints at this process when it names South America "Atlantis" and indicates the presence of anthropophagi or cannibals there. It explicitly draws on literary anthropologies

81 Joseph Addison, “Editorial,” The Spectator 1.47 (24 April 1711), pp. 1-2.

82 Ralf Haekel, Die Englischen Komödianten in Deutschland: Eine Einführung in die Ursprünge des deutschen Berufsschauspiels (Heidelberg: Winter, 2004), p. 236, p. 236, n. 602; my translation ("Die meisten Namen des Narren bezeichnen Speisen."; "Pickelhering leitet sich vom englischen 'pickled herring', also von gepökeltem Hering ab [...].”).

83 Katritzky, “Literary Anthropologies and Pedro González, the ‘Wild Man’ of Tenerife,” in: John Slater, Maríaluz López-Terrada, and José Pardo-Tomás, eds., Medical Cultures of the Early Modern Spanish Empire (Farnham/Burlington, VT: Ashgate, 2014), pp. 107-128. 
to describe and depict a whole range of Old and New World "Indians," each identical to one or another of the familiar classical literary anthropologies. Some are physically distinctive, such as hairy satyrs or wild people, those who use one foot as a sun-shade, one-eyed or two-headed peoples, the Blemmyes (whose heads were located on their chests), the Dog-heads, the long eared ones, pygmies, mermaids or Amazons. As well as the anthropophagi or cannibals, those distinguished primarily by dietary rather than physical characteristics include the astomi, who nourished themselves by smelling apples, and the ichthyophagi or fish-eaters, these latter variously identified by classical anthropologists as Ethiopian or Persian. ${ }^{84}$ An account of them in the early medieval Liber monstrorum provides insights into why early modern illustrators often depicted them hairy and unclothed, much as they then depicted wild men of the woods:

[I]n India next to the Ocean we have learnt of a certain race of humans hairy in their whole body, who are said to live on water and raw fish, covered in natural nakedness only by bristles like wild animals. And the Indians call them Ichthyophagi, and they are not only accustomed to the land, but dwell in streams and ponds and mostly next to the river Epigmaris. ${ }^{85}$

After the Reformation, regional fish-eating practices acquired complex layers of connotations in the light of diverging Catholic, Lutheran and Calvinist fasting regulations. ${ }^{86}$ Early modern fasting regulations were not always transparent. In 1549, for example, compulsory Friday fish-eating was reinstated in some Protestant regions of Northern Germany. To decrease the risk of being caught and punished by the authorities for not observing fish fasts when dining at inns during the 1590s, the Swiss physician Thomas Platter the Younger sometimes ordered forbidden foods such as duck, meat or eggs to be served to him in a private dining room. While visiting London in Autumn 1599, he was surprised to learn that Protestant England still observed both the traditional Lenten fish fast, and year-round weekly two-day fish fasts. ${ }^{87}$ The exact extent of any impact of cultural

84 Gordon Lindsay Campbell, Strange Creatures: Anthropology in Antiquity (London: Duckworth, 2006), pp. $86 \mathrm{f}$.

85 Liber monstrorum: Latin-English, in: Andy Orchard, Pride and Prodigies. Studies in the Monsters of the Beowulf-Manuscript (Toronto: University of Toronto, 2003), pp. 254-315, p. 269 ("Et in India iuxta Oceanum pilosum toto corpore quoddam genus humanum didicimus, qui in naturali nuditate setis tantum more ferino contecti crudis cum aqua piscibus ita uiuere dicuntur. Quos Indi Ichthyophagos appellant. Qui non tantum in terris adseti, sed fluminibus ac stagnis et iuxta amnem Epigmaridem maxime demorantur.” p. 268).

86 My thanks to Bob Kolb and Charlotte Colding Smith for helpful discussions on this point.

87 Thomas Platter d. J., Beschreibung der Reisen durch Frankreich, Spanien, England und die Niederlande 1595-1600, ed. Rut Keiser, 2 vols. (Basel/Stuttgart: Schwabe, 1968), vol. 2, p. 824; Katritzky, Healing, Performance and Ceremony, p. 66. 
memories of classical fish-eaters, or practices of religious fish fasts, on fish-based early modern clown names is unclear, as is any cross-influence between stage names chosen by Italian or English actors. However, given their perceived links with religious fasting practices, fish-based stage names undoubtedly provided excellent opportunities for pointed covert theatrical references to national and confessional variations in religious practices. ${ }^{88}$

Early modern theatre and print culture acknowledge strong connections between the clear class divide in early modern London fish-eating and social drinking habits. Prince Hal bemoans the wanton extravagance of Falstaff's "intolerable" consumption of "Item, Anchoues and Sacke after Supper ii.s.vi.d,"89 while one of George Wilkins' dramatic dialogues notes that a newly wealthy character "[...] feedes now vppon Sacke \& Anchoues [...]," 90 and for Ben Jonson, “[...] a dish of pickled Saylors, fine salt Sea-boyes, shall relish like Anchoues, or Caueare, to draw downe a cup of nectar, in the skirts of a night." 91 John Marston contrasts "good meate, Anchoues, cauiare" with "bottle ale \& red Herrings," 92 and Pasquils Iestes emphasises the lowly status of beer and herrings when evoking "[...] a certaine Alehouse or Inne, where couetous wretches [...] feede vpon browne bread, and red Herrings." ${ }^{93}$ While poor folk ate North Sea herring with their beer not just during fish fasts, but as an everyday food staple, wealthy drinkers accompanied their after-dinner wine with exotic preserved fish specialities, of the type available in the four London wine bars personally vetted by the indefatigable John Taylor, for his exhaustively comprehensive “rough guide” of 1636 to London's drinking venues. All run by Dutchmen, they sold Rhine wines accompanied by salted meats, pickled herrings, anchovies, caviar and botargo. ${ }^{94}$ Tuna or cod roe

88 On the religious and philosophical context of the commedia dell'arte, see Katritzky, Healing, Performance and Ceremony, esp. chaps. 14-15, pp. 245-282; Matt Cawson, "Corporeality and Subversion in Post-Renaissance Italy: The Inquisition and the Commedia dell'Arte," Platform 7.1 (2013), pp. 26-41.

89 Shakespeare, Comedies, histories, \& tragedies, p 60 (1 Henry IV, 2.4). N.B. The currency notation refers to two shillings and sixpence, equivalent to 30 pennies, or twelve and a half new pence, or one eighth of a pound.

90 George Wilkins, The Miseries of Inforst marriage: As it is now playd by his Maiesties Seruants (London: George Vincent, 1607), sig. E4r.

91 Ben Jonson, Neptvnes Trivmph for the return of Albion (s.l., 1623), sig. C2v.

92 John Marston, What You Will (London: Thomas Thorpe, 1607), sigs. C2r, F2v-3r.

93 Pasquils Iestes: Mixed with Mother Bunches 'Merriments' (London: John Browne, 1609), sig. F2r; see also Thomas Dekker, Blurt master-constable: Or The Spaniards night-walke As it hath bin sundry times priuately acted by the Children of Paules (London: Henry Rockytt, 1602), sig. B3v. 94 John Taylor, Taylors travels and circvlar perambvlation, through [...] the Famous Cities of London and Westminster: [...] with an Alphabeticall Description, of all the Taverne Signes [...] (London: A[ugustin] M[atthews], 1636), sig. D7r. 
that has been preserved by being pressed, dried and salted, and traditionally manufactured in Mediterranean regions such as Iberia, France and Italy, botargo is perhaps most familiar to contemporary northern Europeans as the main ingredient of taramasalata. Like pickled herring, it is typically served with alcoholic drinks, in which context it is praised by writers such as François Rabelais, ${ }^{95}$ John Fletcher ("Andrew: There's a Fishmongers boy with Caviar Sir, / Anchoves and Potargo, to make ye drinke.") ${ }^{96}$ and Samuel Pepys. One "very hot" moonlit June evening in 1661, the diarist Pepys, who served botargo to specially favoured guests, sat out in his London garden until midnight with his distinguished naval colleague Sir William Penn "[...] talking and singing and drinking of great drafts of Clarret and eating botargo and bread and butter till 12 at night, it being moonshine. And so to bed - very near fuddled." ${ }^{97}$ If the most popular stock comic role of the English actors derives from cheap herrings, it is unsurprising that one of the wealthy masters of the commedia dell'arte takes his stage name from the expensive fish delicacy botargo. For both, the strong link with excessive alcoholic consumption offers clues to their attraction as comic stage names.

This consideration of specific new documentation and possible influences of literary anthropologies and religious fasting traditions indicates new perspectives on the transnational adoption of fish-based stage names, and contributes to moving the debate beyond the simple food-clown formula by informing and complicating the connection between fish speciality and comic stage name. Similar themes featured in the stage names of different European regions, and on commedia dell'arte and English travelling stages the names chosen by actors reflected local considerations of their home and host nations. The most celebrated fish-based Italian stage name was created in Spain and refers to Mediterranean botargo. Whether or not cultural memories of classical fish-eaters influenced this choice of clown name, or even whether Stefanelo Botarga's success in Spain in the 1580s-great enough to have registered by 1585 in German festival culture-influenced the English actors, they in turn created a popular clown in the early seventeenth-century German-speaking regions named after North Sea pickled herring. The impetus for these stage names clearly came neither directly nor solely from the fish itself. Rather than simply reflecting vague late medieval

95 François Rabelais, Gargantua and Pantagruel, trans. Sir Thomas Urquhart and Pierre Le Motteux, Everyman's Library (London: David Campbell Publishers, 1994), p. 30, p. 70, p. 778.

96 John Fletcher, The Elder Brother A Comedie: Acted at the Blacke Friers, by his Maiesties Servants (London: I[ohn] W[aterson] and I[ohn] B[enson], 1637), sig. E2v.

97 Samuel Pepys, The Diary of Samuel Pepys: a new and complete transcription, ed. Robert Latham and William Matthews, 11 vols. (London: Bell and Hyman, 1970-1983), vol. 2 (1971), 1661, p. 115. 
pan-European links between foolery and carnivalesque foods, early modern fish-based stage names complicate culinary connotations with darker literary and other cultural and anthropological associations that stretch back into the classical past, and created opportunities for coded religious, political and social comment on the travelling stages of early modern Europe. 